\title{
LOWER ROAD USER COSTS WITH PRECAST CONCRETE PAVEMENTS
}

\author{
Radan Tomek \\ Czech Technical University in Prague, Czech Republic \\ radan.tomek@fsv.cvut.cz
}

\begin{abstract}
Road user costs (respectively external costs) primarily refer to the monetized components of road (re)construction impacts, such as the user delay costs, vehicle operating costs, crash costs and air/noise pollution costs. The issue of user costs is closely related to decision making on investments in the transport infrastructure. Ability to define and properly estimate the user costs in the framework of road transport in general, while at the same time to find and include their local specifics promises to improve the above mentioned decision making process. The objective of this research paper was to assess the way of lowering these user costs by an alternative approach to the highway reconstruction - with the use of precast concrete pavements. Approaching this technology innovatively promises significant savings of the construction time and consequently the road user costs in comparison to the traditional cast-in-place construction method. Global experience and methods used for the road user costs' estimation were researched and analysed. Real data from a recently completed highway reconstruction project (using the traditional cast-in-place method) were used together with all the available data on socio-economic elements needed for the calculation. It led to an interesting and presumably generally valid result - road user costs, most often utterly ignored by the public investor, are more than double to those of the reconstruction itself. Comparison regarding the user costs' value of both before mentioned technological approaches to the highway reconstruction was then also performed. This led to the conclusion, that using the prefabricated pavements with their much shorter onsite construction period and lower road user costs results in a significant decrease of overall highway reconstruction costs.
\end{abstract}

Keywords: highway reconstruction, precast pavement, prefabrication, road user cost.

\section{Introduction}

With the ever increasing volume of passenger and freight road transport, the need for maintenance and reconstruction of existing highways is growing. Especially for those routes that are of key importance to each country, the consequences of their reconstruction closures for society are particularly costly and restrictive. However, road transport has not only a positive impact on the overall development of society, but also brings about side effects. Such side effects lead to different resource costs that can be expressed on an economic level. When these side effects of the highway (re)construction bring additional costs to the society, they can be referred to as external or user costs. These are, in particular, the travel delay costs, vehicle operating costs, increased risk of accidents and consequent decrease in productivity costs and the emission cost [1]. All of these were estimated on a specific reconstruction project as part of this research.

Out-of-site externalities such as noise and impact on the local community and business were not included in this research for user costs estimation (as further explained in the Non-monetary impacts paragraph). These non-monetary impacts are hard to value because the factors affecting their estimation are often very specific and no precise method or tool for their calculation has yet been developed [2].

The main objective of the European Union's program HEATCO (Harmonized European Approaches for Transport Costing and Project Assessment) was to propose common guidelines for the evaluation of transport projects within the EU in the following areas: time delays and congestion, injury risk reduction, the cost of health impacts caused by pollutants and noise, and the wider economic and indirect impacts of investment projects [2].

\section{Research approach}

To be able to reach the goal of this research - i.e. to determine the possibilities of precast technology in lowering the costs that highway reconstructions bring to all the network's users - an already completed reconstruction project was closely analysed and all user costs associated with it were precisely calculated. This project was carried out by the standard cast-in-place method and its very exact duration and costs were known. Analysing a variety of similar types of highway reconstruction projects done by the precast pavement technology, the data on standard duration of 
such projects were obtained. Using these, it was at the end possible to estimate the time that would be needed to carry out the very same task using the further described precast pavement technology and its possible user costs.

\section{Precast Concrete Pavement Method}

In the precast concrete pavement system construction, adjacent panels are assembled sequentially and tied together onsite through either post-tensioning or cast-in-load transfer systems. Precast concrete pavement systems can be used for single-lane replacements, multiple-lane replacement (an additional lane may be needed to accommodate materials and equipment) or full-width road construction [3].

Using the precast concrete parts for the road pavement, speeds up the construction time two to three times against the traditional cast-in-place approach, if well organized. Such a pavement can be used, i.e. driven on the very next day after its installation as no curing of the newly laid road surface is further necessary [4]. To demonstrate the nature of this quite innovative precast approach the very successful application in a heavy-traffic area around Washington D.C., USA can be given as a model example.

Conventional repair with cast-in-place concrete would have required about 100 days with traffic congestion from lane closures, but the precast slab approach allowed closure of one lane at a time for about 35 nights of work and made all lanes available for rush-hour traffic. Every night's cycle included the removal of the existing concrete, preparation and grading of the roadway sub-base and preparation and placement of the new pavement slabs [3].

\section{User cost estimation}

As mentioned above, for the purpose of this research an extensive set of unique data from already completed reconstruction project ("Section 05" at kilometres 41-49 of the backbone Czech highway D1, see Fig. 1 below) was gathered. These data were not only of a generally available kind, e.g. on air pollution in the monitored area or statistics of the Czech or European Statistical Office, but in particular project documentation, technical report and traffic engineering measures of the project, which are essential for the user costs' estimation. Due to the large volume of data and performed calculations, this paper does not provide its full extent, but outlines the method and lists the summarized results only.

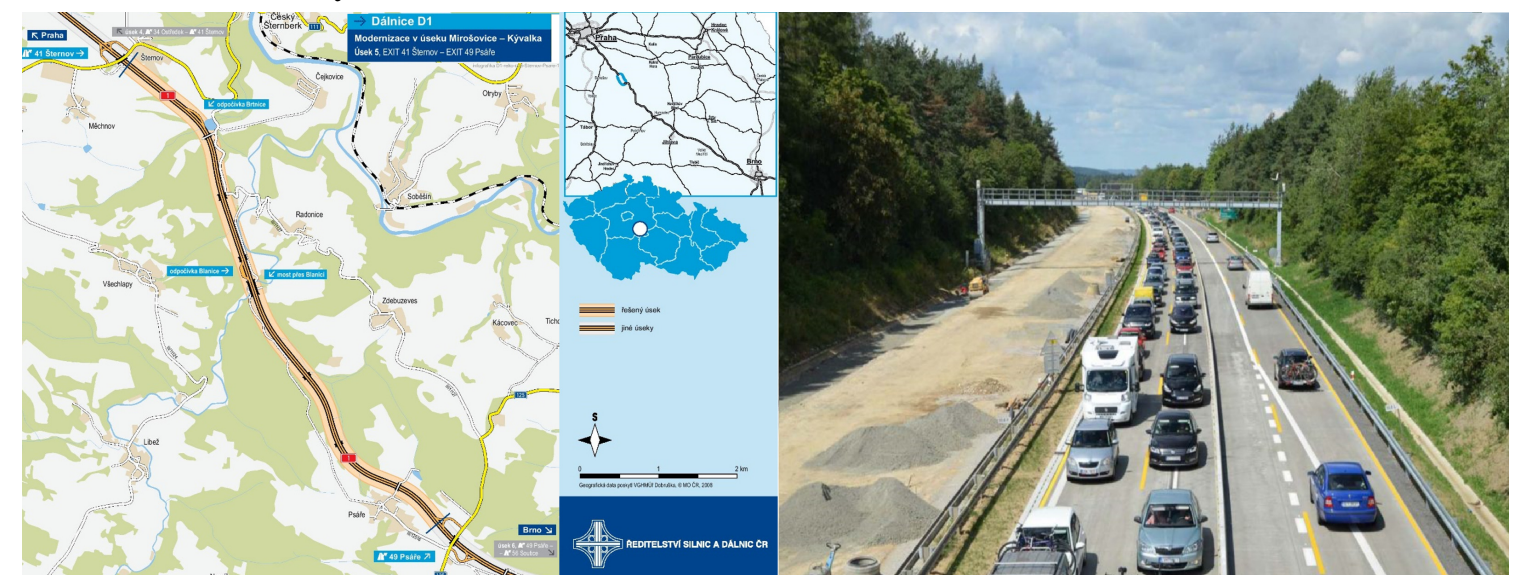

Fig. 1. Location of estimated reconstruction project and $2+2$ traffic lane arrangement during work

The main selection criterion was the fact that the reconstruction of this section was already completed and all actual data were available in full detail (and so the estimates could be made up to single euros). It was also approached in the usual way - concentrating the traffic into one direction, while keeping the same amount of lanes accessible (i.e. $2+2$ ), as shown in Figure 1 - while fully closing and working on the other direction of the road. Another important selection criterion was the fact that it has an overall profile (length, number of bridges, elevation profile) representing a typical D1 highway section. The project was commissioned by the Czech State Highway Directorate, the 
general contractor was Eurovia CS Corp. and the total construction cost of the project was 19,373,906 EUR.

\section{Travel delay costs}

Travel delay is the extra time it takes to travel through the work area or time to detour the area. The total amount of the travel delay user costs will be based on the sum of the costs of delays of business travellers, private travellers and the costs of delaying the transport of goods. It is possible to estimate these user costs by multiplying the sum of extra time (i.e. time additionally spent on the road due to work on the road) of all these types of road users with the monetary values (EUR per day) of their travel time, respectively delay:

$$
T D C=M V_{B T T}+M V_{P T T}+M V_{B D}+M V_{F T},
$$

where $T D C-$ travel delay costs, EUR $\cdot$ day $^{-1}$;

$M V_{B T T}-$ monetary value of business travel time, EUR $\cdot$ day $^{-1}$;

$M V_{P T T}$ - monetary value of personal travel time, EUR $\cdot$ day $^{-1}$;

$M V_{B D}$ - monetary value of bus delay (i.e. both, business and personal travel), EUR $\cdot$ day $^{-1}$; $M V_{F T}$ - monetary value of goods transport delay, EUR $\cdot$ day $^{-1} ;$.

For the travel delay user costs' estimation, it was necessary to know the economic values per hour of a certain type of delay. These data were mostly provided by the HEATCO study [2]. It was necessary to know the average occupancy rate of passenger cars, which is 1.9 persons per vehicle [5]. The average bus occupancy is 36 people per bus, according to the same source. The public transport forecast predicts the ratio between private and business related journeys to be 80 to $20 \%$ [6]. To estimate the user costs of goods delay, it is necessary to know the average loading of the truck in the Czech Republic. According to the Eurostat statistics [7], the average truck load is 12 tonnes. It is also necessary to know the annual average daily traffic intensities in the analysed section of the highway. These data are provided by the Road and Motorway Directorate [8]. It is also necessary to take into account different traffic intensities during the day in order to calculate more accurately the user cost of the delay. These data were obtained from traffic surveys commissioned by the Ministry of Finance of the Czech Republic and from the Determination of Traffic Intensity research [9].

Thus, the user costs of the travel delay for the analysed section of the D1 motorway during its reconstruction were in total estimated to EUR 48,383,769.

\section{Crash costs}

According to the HEATCO study [4], the costs of increased risk of accidents can be expressed as:

$$
\sum_{i}=r_{i} \cdot n_{i} \cdot v k m
$$

where $i$-type of accident (death, serious injury, light injury, property damage)

$r_{i}$ - risk by the type of traffic accident's consequence per vehicle-kilometre

$n_{i}-$ cost by type of traffic accident consequence

$v k m$ - vehicle-kilometre.

The calculation of crash costs is based on accident data in a given section of the D1 Highway. For the initial part of the estimation it was necessary to know the length of the working zone and the total time for which traffic restrictions were planned. Data on all reported traffic accidents were obtained from the database of the Ministry of Transport of the Czech Republic [10]. Unreported accidents were multiplied by correction coefficients for unreported traffic accidents according to the European guidelines [2] over a period of six years prior to reconstruction and compared with accidents during the reconstruction itself. The cost of increased risk of accidents can be defined as a multiple of the risk rate, the size of the cost and the number of vehicle-kilometres for each type of accident [2]. Accident risk rate was obtained as the number of accidents in the monitored highway section divided by a multiple of time, section length and traffic intensity. The average value of property damage per traffic accident was EUR 2,174 [11], the value of death was estimated to be EUR 1,209,242, of serious injury EUR 162,443 and of light injury EUR 11,807. The total user costs of the increased accident risk for the analysed section were estimated to EUR 2,681,620. 


\section{Emission costs}

The last portion of the user costs' estimation within the D1 Highway section 5 reconstruction deals with the emission costs. The estimation is based on reduced speed and emission volumes' changes at these speeds. The resulting value is determined by the difference in the user costs at the time of reconstruction (i.e. at limited speed) and user costs in normal operation.

$$
E C=E C_{W Z}-E C_{N O},
$$

where $E_{C}-$ emission costs, EUR;

$E_{C W Z}-$ emission costs of the working zone, EUR

$E_{C N O}$ - emission costs in normal operation, EUR.

Volumes of emissions applied in the estimate were based on the EMFAC study [12]. Total emission costs were estimated as those incurred during the reconstruction less those present during normal operation (EUR 8,783,336 to EUR 9,121,018). Given that the overall result was negative (EUR -337,682), it can be stated that, when using the rate change as the only variable in the calculation of the user's emissions, the project's traffic restrictions are beneficial to the environment. As this is a change in speed from $130 \mathrm{~km} \cdot \mathrm{h}^{-1}$ to $80 \mathrm{~km} \cdot \mathrm{h}^{-1}$, the results of "Why slower is better" study [13], which indicates the speed of $80 \mathrm{~km} \cdot \mathrm{h}^{-1}$ as optimal for reducing transport emissions, are confirmed.

\section{Non-monetary impacts}

In addition to monetary components, other work zone effects that impact the community at-large are also taken into consideration. These factors are generally hard to monetize and therefore should be considered as non-monetary or qualitative factors in the decision-making process. The key nonmonetary and qualitative factors are the noise and local business and societal impacts [14]. Little information is available on monetizing the damage caused by these impacts, respectively they are hard to estimate and represent a special subject for further research. Contrary to the above estimated emission costs, it is clear that due to their nature, these non-monetary impacts will always have an overall negative effect on the highway users/local population/society. However, it is beyond the scope of this research.

\section{Total user cost for the analysed section of Highway D1}

Total user cost of the analysed section is given by the sum of all the above estimated costs, i.e.:

Total user costs $=$ Travel delay costs + Crash costs + Emission costs $=$

$=$ EUR 48,383,769 + EUR 2,681,620 - EUR 337,682 = EUR 50,727,707

The value of the user costs for the analysed section was set at EUR 50,727,707 for the period of its reconstruction. Compared to the total construction cost of the project, which was EUR 19373906 , the user costs turned out to be much higher than those of the construction itself - more than 2.6 times, as graphically shown in Fig. 2 bellow.

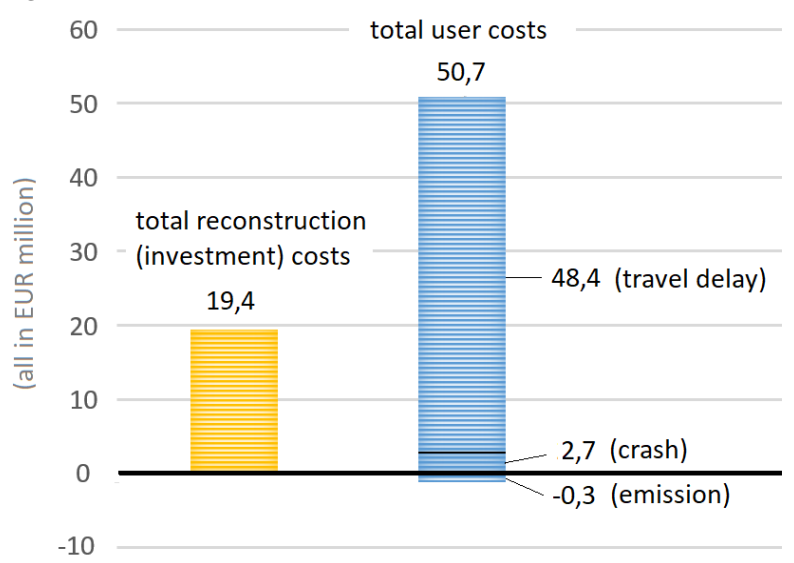

Fig. 2. Road user costs - most often "invisible" to public investor and public as well - are more than double to those of reconstruction itself (in EUR million) 


\section{Construction time reduction with precast pavement approach}

The speediness of the laying precast panels not only results in less traffic congestion and delays, but can lower the user costs significantly. In addition, the precasting is under better controlled environment. It leads to a more durable concrete and requires less maintenance [15]. Most of the weather-sensitive processes are performed in the factory-controlled conditions off the site.

Using the precast pavement method, the daily savings in construction time and user costs can be substantial. Although the initial costs for precast panels may at first be higher, the saving in the user cost is far more than the first construction cost, due to the speed of construction [16]. The analysed project shows that the value of user costs justifies possible application of more expensive advanced accelerated construction methods, like the precast pavement technology, by bringing substantially shorter construction time.

Precast concrete pavement technology can speed up construction without sacrificing quality, while minimizing lane closures and traffic disruption. Off-site fabrication has the potential to permit lighter, thinner, and more durable pavement sections through more stringent quality control and use of design details not feasible for in-place construction [17].

The measured performance outcomes show that using the precast pavement construction approach enables the contractor to replace pavement sections quickly during night time and weekend lane closures, reducing driver impacts by an estimated $70 \%$ over traditional construction methods [3]. The analysed Highway D1 reconstruction project's duration was 507 days. Applying the above mentioned and also on other precast projects standardly experienced saving of $70 \%$ onto the analysed project results in possible time duration of 152 days.

\section{Results and discussion}

As the basis of this research and exact breakdown analysis of user costs components was carried out. User costs are generally high during the highway reconstruction projects and their value increases proportionally with the traffic flow levels. This was shown in the calculation of these costs on the backbone Czech Highway D1 reconstruction project case above with the user costs being 2,6 times higher than the construction investment costs. Because the main factor influencing the user costs value is the construction time needed, precasting the concrete pavements off-site represents a viable solution. Using this approach based on previously presented difference against the standard cast-inplace method might lowers the user costs for the analysed project to EUR 15,218,312, i.e. bringing the user vs. construction costs ratio back to 0.8 .

In general, reduction of the construction time is crucial for the backbone routes with the heaviest traffic, where any congestions due to their closures represent a huge problem with high user costs for the drivers and society. It can be highly recommended because of the substantial time savings.

Higher initial capital investment requirements (mainly due to expensive prefabrication plant and transport equipment) can be an obstacle for the larger scale application of the precast pavement technology.

\section{Conclusions}

1. Road user costs, most often utterly ignored by the public investor, are more than double to those of the reconstruction itself.

2. Travel delay costs account for the vast majority of the total user costs that are incurred during the reconstruction project, respectively due to driving lane's closures in general.

3. Using the prefabricated pavements with their much shorter onsite construction period, results in a significant decrease of the road user costs.

4. User costs due to highway reconstruction being higher than the construction costs justify possible application of a more expensive advanced accelerated construction method, like the precast pavement technology, by bringing substantially shorter construction time.

5. Ability to correctly value the user costs is crucial for correct assessment of the construction/reconstruction project feasibility and overall project costs. 


\section{Acknowledgements}

This work was supported by the Grant Agency of the Czech Technical University in Prague, grant No. SGS19/016/OHK1/1T/11.

\section{References}

[1] Korzhenevych A., Brocker J., Gibson G. Update of the Handbook on External Costs of Transport. Harwell, 2014. ED 57769.

[2] Bickel P, Friedrich R., Burgess A. HEATCO Developing Harmonised European Approaches for Transport Costing and Project Assessment: Proposal for Harmonised Guidelines. 2nd ed. IER Germany, 2006.

[3] Portland Cement Association: Precast Concrete Pavement Systems Save Time, Cut Congestion on Highway Repair. Roads \& Bridges magazine, Scranton Gillette Communications. [online] [1.5.2019]. Available at: https://www.roadsbridges.com/precast-concrete-pavement-systems-savetime-cut-congestion-highway-repair

[4] Tomek R. User costs as one of main advantages of precast concrete application in highway construction. 2017 IOP Conf. Ser.: Mater. Sci. Eng. 236012111

[5] Příručka Indikátory pro monitoring a hodnocení Operačního programu Doprava (Handbook Indicators for Monitoring and Evaluation of the Operational Program Transport). Ministry of Transport of the Czech Republic, Prague, 2010.

[6] RAILHUC - Přepravní prognóza ve veřejné dopravě: přsstupní terminály a páteřní sít' veřejné dopravy Kraje Vysočina (RAILHUC - Transport forecast in public transport: transfer terminals and backbone network of the Vysočina Region public transport). [online] [1.5.2019]. Available at: http://m.kr-vysocina.cz/assets/File.ashx?id_org $=450008 \& i d \_d o k u m e n t y=4056011$

[7] Průměrné naložení kamionu (Average truck loading). Eurostat: Statistics Explained. [online] [1.5.2019]. ISSN 2443-8219. Available at: https://ec.europa.eu/eurostat/statisticsexplained/index.php/Road_freight_transport_by_journey_characteristics

[8] Celostátní sčítání dopravy 2016 (Nationwide traffic census 2016). ŘSD ČR, 2016. [online] [1.5.2019]. Available at: http://scitani2016.rsd.cz/pages/map/default.aspx

[9] Bartoš, L. Stanovení intenzit dopravy na pozemních komunikacích: TP 189 (Determination of traffic intensity on roads: TP 189). EDIP, 2nd ed. Pilsen, 2012. ISBN 978-80-87394-06-9.

[10] Statistické vyhodnocení nehod na trase (Statistical evaluation of road accidents). Ministry of Transport of the Czech Republic, Prague, 2018. [online] [1.5.2019]. Available at: http://maps.jdvm.cz/cdv2/apps/nehodynatrase/Search.aspx

[11] Přehled o nehodovosti na pozemních komunikacích v České republice za rok 2016 (Road accident survey in the Czech Republic for 2016). Police of the Czech Republic, Prague 2017. [online] [1.5.2019]. Available at: https://www.policie.cz/clanek/statistika-nehodovosti-900835.aspx?q = Y2hudW09Mw \%3d \%3d

[12] California Air Resource Board Information System: EMFAC2017 web database. California Air Resource Board, Sacramento, 2018. [online] [1.5.2019]. Available at: https://www.arb.ca.gov/emfac/2017/

[13] Otten, M., Van Essen, H. Why slower is better: Pilot study on the climate gains of motorway speed reduction. CE Delft, Delft, 2010. [online] [1.5.2019]. Available at: https://www.ce.nl/publicatie/why_slower_is_better/948

[14] Mallela, J. Work zone road user costs: concepts and applications. Washington, DC: U.S. Department of Transportation, Federal Highway Administration, 2011. ISBN FHWA-HOP-12005 .

[15]Chang, L. M., Chen, Yu-Tzu, Lee, S. Using Precast Concrete Panels for Pavement Construction in Indiana, Joint Transportation Research Program Project No. C-36-46X File No. 5-11-24 SPR 2779, School of Civil Engineering Purdue University, 2004.

[16] Merritt, D., McCullough, B.F., Burns, N.H. Feasibility of Using Precast Concrete Panels to Expedite Construction on Portland Cement Concrete Pavements. Paper No. 01-2904, Transportation Research Board, 80th Annual Meeting, January 7-11, 2001, Washington, D.C, Transportation Research Record 1761, pp. 3-9.

[17] Tayabji, S., Buch, N. Performance of Precast Concrete Pavements. First Congress of Transportation and Development Institute (TDI), DOI: 10.1061/41167(398)86 